\title{
Effect of Central Administration of $\beta$-Endorphin on Lung Ornithine Decarboxylase Activity in Developing Rats
}

\author{
NANCY L. GREER, SAUL M. SCHANBERG, AND JORGE V. BARTOLOME \\ Department of Pharmacology, Duke University Medical Center, Durham, North Carolina 27710
}

\begin{abstract}
Results from a number of studies suggest a role for endogenous opioids in the regulation of lung development and function. Although it is not known which opioid peptides are involved in these processes, accumulated evidence suggests a prominent role for $\beta$-endorphin (BE). Our study examines the effect of $\mathrm{BE}$ on lung ornithine decarboxylase (ODC) activity in preweanling rats. ODC catalyzes the rate-limiting step in the synthesis of the polyamines spermidine and spermine, key regulators of cell growth, multiplication, and differentiation. Central (but not peripheral) administration of $\mathrm{BE}$ reduced lung ODC activity by as much as $\mathbf{8 0 \%}$ in the 6-d-old rat. Significant decreases in ODC activity were seen at doses of $\mathrm{BE}$ as low as $0.5 \mu \mathrm{g} / \mathrm{g}$ brain wt. In contrast to the reductions in ODC activity, plasma levels of corticosterone in animals administered $\mathrm{BE}$ were approximately five times higher than those seen in control animals. BE's actions on ODC activity and plasma corticosterone levels were prevented by naloxone or naltrexone, indicating that both responses are mediated by opioid receptors. Studies of ODC kinetics showed a profound reduction in $V_{\max }(70 \%$ below control values), but no change in $\mathrm{Km}$. The effect was observed only during the first 2 wk of postnatal age, a period of time in lung maturation that is characterized by active alveolarization. Because changes in ODC levels during early postnatal life are associated with perturbations in tissue growth and/or function, the data suggest that CNS BE may influence lung maturation through an indirect action that may involve glucocorticoids. (Pediatr Res 29: 182-186, 1991)
\end{abstract}

\section{Abbreviations}

BE, $\beta$-endorphin

ODC, ornithine decarboxylase

i.c., intracisternal

Narcotic addiction during pregnancy retards general fetal growth and increases the incidence of prematurity $(1-3)$. However, it is clinically well recognized that lung function in these low-birth-weight babies is similar to that found in full-term newborn infants, as evidenced by a high lecithin/sphingomyelin ratio and, consequently, by a low incidence of respiratory distress syndrome $(4,5)$. Precocious fetal lung development is also found in animals treated with opioids during pregnancy $(6,7)$, whereas administration of naloxone (a potent opioid antagonist) has an opposite effect (7). The latter finding is important because it

Received October 30, 1989; accepted September 21, 1990.

Correspondence: Jorge V. Bartolome, Ph.D., Department of Pharmacology, Duke University Medical Center, P. O. Box 3813, Durham, NC 27710.

Supported by UPHS Grants RO1-NS-25738 and ROI-MN-13688. indicates that endogenous opioid systems (i.e. opioids and opioid receptors) tonically modulate fetal lung maturation.

Accumulated knowledge suggests that $\mathrm{BE}$ may influence pulmonary development. Pituitary and hypothalamic levels of BE are elevated in fetal and neonatal rats after maternal morphine treatment (8). Plasma BE levels in normal newborn babies are three to four times higher than the concentrations found in their mothers, and decline to adult levels by the 5 th day of life $(9,10)$. In infants of heroin-addicted mothers, plasma BE levels show even larger increases after birth (up to 1000 times adult levels) and remain elevated at $40 \mathrm{~d}$ of age (9). These and other observations support the hypothesis that $\mathrm{BE}$ may have a prominent role in the modulation of lung maturation (11-14).

Studies of the consequences of opioid exposure on lung function have predominantly addressed prenatal effects, primarily due to their relevance to respiratory distress syndrome. However, it is equally important to investigate opioid actions on the postnatal lung. Both the newborn human and rat lungs are extremely immature and undergo vast morphologic restructuring after birth; the majority of alveoli are formed postnatally, increasing from approximately 20 million at birth to 300 million in the mature lung (15-18). The neonatal lung is highly responsive to trophic hormones (19-21). Finally, as the early postnatal lung development (saccular stage) is fundamentally a continuation of the late fetal maturation, the findings obtained during the first days of age essentially reflect prenatal mechanisms.

Our study examines the effect of central administration of BE on lung ODC activity (EC 4.1.1.17) in developing rats. ODC catalyzes the formation of putrescine from ornithine, the ratelimiting step in the synthesis of the polyamines spermidine and spermine, thought to be essential for normal tissue maturation $(22-24)$. Due to its extremely short $t^{1 / 2}(10$ to $20 \mathrm{~min})$, ODC activity is susceptible to rapid and profound change. ODC levels are highest during accelerated cellular growth, multiplication, and differentiation, and decrease quickly as these processes decline. Each tissue has a characteristic ontogenetic pattern of ODC activity (22), and perturbations of these patterns are associated with subsequent alterations in tissue growth and function (2528 ). The rat lung exhibits a parallel increase in ODC activity and alveolarization during the 1st week of postnatal age $(16,17,29)$, and both events are reduced in animals administered $\alpha$-difluoromethylornithine (a specific inhibitor of ODC activity), thus confirming a critical role for this enzyme in pulmonary development (29).

\section{MATERIALS AND METHODS}

Animals and drug treatments. Timed-pregnant Sprague-Dawley rats (Zivic-Miller Laboratories, Allison Park, PA) were housed individually in breeding cages in a vivarium maintained at $22^{\circ} \mathrm{C}$ on a 12-h light-dark cycle (0700-1900 h), with food (Purina Lab Chow, Ralston-Purina, St. Louis, MO) and water available ad libitum. The day after birth, litters were randomized and culled 
to 10 or 11 pups/dam to maintain a uniform nutritional and maternal status. Animals were transported to the laboratory the day before experimentation and randomized among dams. The day of the experiment, pups were again randomized and, in addition, various treatment groups were distributed among several litters to minimize nutritional or maternal differences. Animal care at Duke University is governed by the Duke University Institutional Animal Care and Use Committee and the Guide for the Care and Use of Laboratory Animals, published by the Public Health Service. Animal facilities are fully accredited by the American Association for the Accreditation of Laboratory Animal Care.

Two, 6-, 10-, 14-, or 18-d-old rat pups were injected i.c. with 0.25 to $1.5 \mu \mathrm{g} \mathrm{BE} / \mathrm{g}$ brain wt or saline and killed by decapitation $4 \mathrm{~h}$ later. Whole lungs were quickly dissected and weighed before analysis. In another set of studies, 6-d-old rats were injected s.c. with $\mathrm{BE}$ or saline and killed $4 \mathrm{~h}$ later. Injection volumes were 5 $\mu \mathrm{L}$ for 2-d-old pups and $10 \mu \mathrm{L}$ for 6-, 10-, 14-, and 18-d-old pups for i.c. injections and $1 \mu \mathrm{L} / \mathrm{g}$ body wt for s.c. injections. In 2 and 6-d-old pups, i.c. injections were given through the bregma, whereas older animals were injected via the foramen magna because the bregma landmark becomes less apparent with age (due to the appearance of hair and thickening of the skull). Identical drug distribution patterns throughout the cerebral ventricular systems were verified in rats injected with methylene blue. Mean brain weights from previous studies were used to calculate the doses of $\mathrm{BE}(\mu \mathrm{g} / \mathrm{g}$ brain wt) for the i.c. injections. Actual individual values measured post-mortem fell within $5 \%$ of the mean calculated dose. Intracisternal injections were performed under light ether anesthesia.

ODC responses to hypoxia were examined by separating 6-dold pups from their dams and placing them in a covered $6-\mathrm{L}$ plastic pan kept at $37^{\circ} \mathrm{C}$ in an incubation bath. The container was then ventilated for 1,2 , or $4 \mathrm{~h}$ with warmed, humidified room air (controls) or warmed humidified $7 \%$ oxygen $+93 \%$ nitrogen at a rate of $15 \mathrm{~L} / \mathrm{min}$ (30). Under these conditions, the $\mathrm{PO}_{2}$ of source and exhaust gases were equal. Because studies in our laboratory have demonstrated that even a short-term separation of developing rat pups from their dams evokes a decrease of ODC activity in most tissues (31), simultaneous measurements were conducted in animals that were left with their dams and not gassed. The data was then compared with that obtained in littermates that went through the separation procedure and were exposed to room air in the apparatus.

Synthesis of proteins in vivo was evaluated by measuring incorporation of $\left[{ }^{3} \mathrm{H}\right]$ leucine into proteins as described in detail in an earlier publication (32).

$O D C$ activity. Whole lung was homogenized (Polytron) in 19

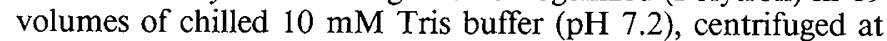
$26000 \times g$ for $20 \mathrm{~min}$, and ODC activity measured in the supernatant by a modification of the method of Russell and Snyder (33). The incubation medium contained $0.9 \mathrm{~mL}$ of supernatant, and final concentrations of $4.8 \mu \mathrm{M} \mathrm{L}-\left[1-{ }^{14} \mathrm{C}\right]$ ornithine, $1.8 \mathrm{mM} \mathrm{DTT}$, and $50 \mu \mathrm{M}$ pyridoxal-5'-phosphate in a total volume of $1 \mathrm{~mL}$. Incubation vials were capped with serum stoppers into which center wells containing paper filter wicks had been fitted. After a 30 -min incubation at $37^{\circ} \mathrm{C}, 0.5 \mathrm{~mL}$ of $10 \%$ trichloroacetic acid was added to stop the reaction and then $0.2 \mathrm{~mL}$ of hyamine hydroxide was added to the paper wicks to trap the liberated ${ }^{14} \mathrm{CO}_{2}$ during a second 30 -min incubation. Center wells were placed in scintillation fluid and counted for radioactivity. ODC activity is expressed as nmol ${ }^{14} \mathrm{CO}_{2}$ evolved/ $\mathrm{g}$ of lung/h.

Determination of enzyme kinetics of $O D C$. Four h after i.c. administration of $1.5 \mu \mathrm{g} \mathrm{BE} / \mathrm{g}$ brain wt or saline to 6-d-old rats, lung ODC activity was measured (in triplicate) in pooled supernatants from each treatment group, using a range of $L$-ornithine concentrations from 2.43 to $155.2 \mu \mathrm{M}$ as previously reported by us and other investigators (34-36). ODC activity at the different concentrations of ornithine was then analyzed by linear regres- sion using a double reciprocal plot to obtain the $\mathrm{Km}$ and $\mathrm{V}_{\max }$ for each treatment. To ensure that the measured enzyme activity did not result from nonspecific decarboxylation (which might be found when high concentrations of ornithine are used), lung ODC activity was also determined in a different group of rats given a maximally effective dose of $\alpha$-difluoromethylornithine, a specific, potent, and irreversible inhibitor of ODC activity (37). The residual enzyme activity after $\alpha$-difluoromethylornithine treatment was then subtracted from the total ODC values at each ornithine concentration. Nonspecific activity ranged from 5 to $20 \%$ of the total ODC values.

Corticosterone concentrations. Blood was collected into polystyrene tubes, allowed to clot at $4^{\circ} \mathrm{C}$ for $10 \mathrm{~min}$, and then centrifuged at $1000 \times g$ for $10 \mathrm{~min}$. Serum was stored at $-40^{\circ} \mathrm{C}$ until assayed. Corticosterone was assayed by RIA after extraction from serum with ethylacetate using antiserum and corticosterone standard supplied by Radioassay Systems Laboratories, Inc. (Carson City, CA) and $\left[{ }^{3} \mathrm{H}\right]$ corticosterone from New England Nuclear (Boston, MA). Sensitivity of the assay was $0.1 \mathrm{ng} / \mathrm{mL}$.

Materials. BE [human $\beta$-lipotropin (61-91)] and metenkephalin were obtained from Peninsula Laboratories, Inc. (Belmont, $\mathrm{CA}$ ), naloxone $\mathrm{HCl}$ from Endo Laboratories, Inc. (Garden City, NY), and $\mathrm{L}-\left[1-{ }^{14} \mathrm{C}\right]$ ornithine monohydrochloride (51.6 $\mathrm{mCi} / \mathrm{mmol})$ and $\mathrm{L}-\left[3,4,5-{ }^{3} \mathrm{H}(\mathrm{N})\right]$ leucine $(143.0 \mathrm{Ci} / \mathrm{mmol})$ from New England Nuclear Corp. (Boston, MA). DL- $\alpha$-difluoromethylornithine (MDL $71782 \mathrm{~A}$ ) was kindly provided by Dr. P. McCann, Merrell Dow Research Institute (Cincinnatti, OH). Pyridoxal-5' -phosphate and L-ornithine hydrochloride were obtained from Sigma Chemical Co. (St. Louis, MO), DTT from Bachem Inc. (Torrance, CA), and hyamine hydroxide (scintillation grade) from Research Products International Corp. (Mount Prospect, IL).

Statistics. Data are reported as means \pm SEM. Statistical analysis used two- or three-way analysis of variance as indicated, followed post hoc by either Duncan's multiple range test or $t$ test (two-tailed, unpaired) where appropriate. Significance was tested at $p<0.05$.

\section{RESULTS}

Effect of BE on lung ODC activity in 6-d-old rats. Administration of BE i.c. produced a dose-related decrease in lung ODC activity (Fig. 1). Enzyme activity in animals given the highest dose $(1.5 \mu \mathrm{g} / \mathrm{g}$ brain wt) was reduced to approximately $20 \%$ of control values.

Because tissue ODC responses to i.c. BE could result from direct peripheral actions of this neuropeptide after its leakage

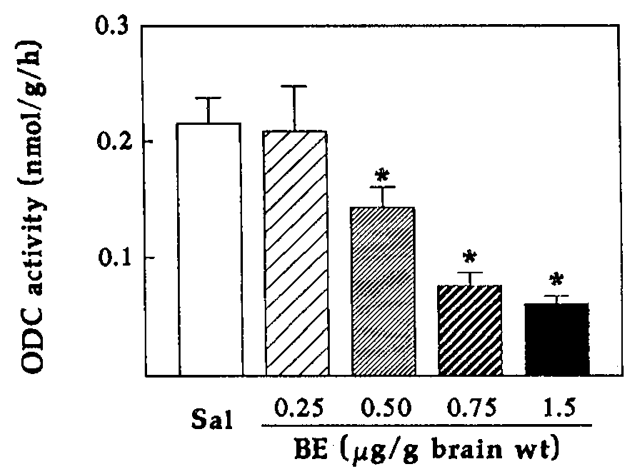

Fig. 1. Dose-response effect of central administration of BE on lung ODC activity in 6-d-old rats. Animals were injected i.c. with $\mathrm{BE}$ at the doses indicated above or with saline, and ODC activity was assayed $4 \mathrm{~h}$ later. Data represent the means \pm SEM of values from two or three experiments using 8 animals/group/experiment. One-way analysis of variance indicates a significant effect of $\mathrm{BE}\left(\mathrm{F}_{4}=15.2 ; p<0.01\right)$. Asterisks denote significant differences of individual $\mathrm{BE}$ groups $v s$ saline as evaluated by Duncan's multiple range test ( $p<0.05$ or less). 
into systemic blood, similar studies were conducted in a different group of rats treated s.c. with BE. Peripheral administration of 0.5 or $1 \mu \mathrm{g}$ of $\mathrm{BE}$, amounts equivalent to those given centrally ( 0.75 or 1.5 on a $\mu \mathrm{g} / \mathrm{g}$ brain wt basis, respectively), or even 10 $\mu \mathrm{g}$ of BE had no overall significant effect on ODC activity (data not shown).

Mechanisms underlying effect of $B E$ on lung $O D C$ activity in 6-d-old rats. To determine whether the effect of CNS BE on lung ODC activity is mediated by classical opioid receptors, similar studies were conducted in animals treated with $3 \mu \mathrm{g}$ of naloxone/ $\mathrm{g}$ brain wt (a dose shown to block brain opioid receptors in the rat) $(14,38)$. Coadministration of naloxone with $\mathrm{BE}$ i.c. reversed the decreases in ODC activity normally seen in rat pups given BE (Fig. 2). Naloxone alone did not significantly alter basal lung ODC levels.

Kinetic studies were undertaken to establish whether BE actions on lung ODC activity reflect changes in enzyme affinity or $\mathrm{V}_{\max }$. As shown in Figure 3, BE treatment evoked a dramatic reduction in $\mathrm{V}_{\max }$ (from 10.53 in controls to $3.13 \mathrm{nmol} / \mathrm{g} / \mathrm{h}$ in BE-treated animals) without a significant change in $\mathrm{Km}$.

Glucocorticoids have been shown to delay the pattern of cellular development in rat lung, in part, by acting on ODC activity (26). Thus, it is possible that the lung ODC responses we observed in rat pups given $\mathrm{BE}$ i.c. reflect actions of this neuropeptide on plasma corticosterone levels. As shown in Figure 4, plasma corticosterone was $25 \pm 3 \mathrm{ng} / \mathrm{mL} 1 \mathrm{~h}$ after receiving $\mathrm{BE}$, a value approximately five times higher than that seen in control animals. As was the case for ODC, the corticosterone effect was

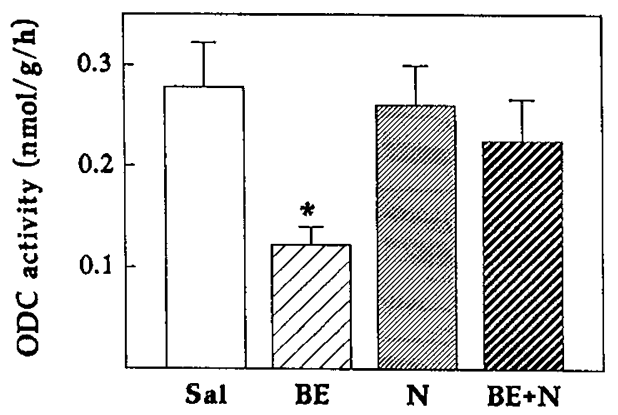

Fig. 2. Effect of central administration of naloxone on the decreases in ODC activity evoked by BE in 6-d-old rats. Animals were injected i.c. either with $1.5 \mu \mathrm{g} \mathrm{BE} / \mathrm{g}$ brain wt, $3 \mu \mathrm{g}$ naloxone/g brain wt, $\mathrm{BE}$ plus naloxone, or saline, and ODC activity was measured $4 \mathrm{~h}$ later. Data represent the means \pm SEM of values from 14 or 15 animals/group. The $t$ test indicates a significant difference only for BE $v s$ saline $(p<0.005)$.

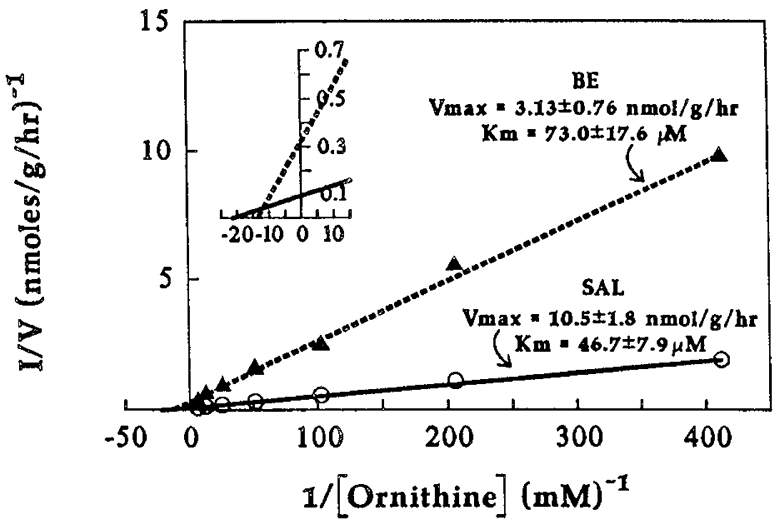

Fig. 3. Pharmacokinetic analysis of ODC activity. Pooled lung preparations from 6-d-old rats treated i.c. with $\mathrm{BE}(1.5 \mu \mathrm{g} / \mathrm{g}$ brain wt) or saline were analyzed for ODC activity against a range of L-ornithine concentrations from 2.43-155.2 $\mu \mathrm{M}$. Linear regression analysis $(r$ for saline $=0.998 ; r$ for $\mathrm{BE}=0.998)$ indicates a significant reduction in $\mathrm{V}_{\max }$ $(p<0.02)$ without a change in $\mathrm{Km}$ after $\mathrm{BE}$ treatment.



Fig. 4. Effect of central administration of BE and/or naltrexone on plasma corticosterone levels. Animals were injected i.c. either with 1.5 $\mu \mathrm{g} \mathrm{BE} / \mathrm{g}$ brain wt, $4 \mu \mathrm{g}$ naltrexone $(N A L T X) / \mathrm{g}$ brain wt, $N A L T R X+$ $B E$, or saline, and plasma corticosterone was measured $1 \mathrm{~h}$ later. Data represent the means \pm SEM of values from five or six determinations (2 animals/determination/group. The $t$ test indicates a significant difference only for BE $v s$ saline $(p<0.001)$.

Table 1. Effect of hypoxia $\left(7 \% \mathrm{O}_{2}\right)$ on lung $O D C$ activity in 6-d-old rats*

\begin{tabular}{ccc}
\hline & \multicolumn{2}{c}{ ODC activity $(\mathrm{nmol} / \mathrm{g} / \mathrm{h})$} \\
\cline { 2 - 3 } Time $(\mathrm{h})$ & Air & $7 \% \mathrm{O}_{2}$ \\
\hline 1 & $0.121 \pm 0.019$ & $0.627 \pm 0.087 \dagger$ \\
2 & $0.186 \pm 0.063$ & $2.33 \pm 0.45 \dagger$ \\
4 & $0.141 \pm 0.036$ & $2.13 \pm 0.45 \dagger$ \\
\hline
\end{tabular}

* Animals were removed from the dam and placed in the gassing chamber. The containers were then gassed with air or $7 \% \mathrm{O}_{2}$ for the times indicated above, and animals were immediately killed afterward. Lung ODC activity in rat pups that remained in the home cage with the dam for the duration of the experiment was $0.342 \pm 0.087 \mathrm{nmol} / \mathrm{g} / \mathrm{h}$. Data represent the means \pm SEM of values from 8 to 10 animals/group.

$\dagger$ Significantly different from control group ( $p<0.05$ or less; $t$ test).

totally reversed by naltrexone (a long-lasting opioid antagonist) (Fig. 4).

Central administration of $\mathrm{BE}$ has been reported to depress respiration in dogs (39). Similarly, in human studies exogenous opiate alkaloids inhibit respiration as well as ventilatory responses to hypoxia and hypercapnia (40). Thus, it is conceivable that the decreases in lung ODC activity that we have observed in BE-treated pups may be related to a decline in cell metabolism usually associated with ventilatory depression. One way to investigate this possibility is by assessing the effect of hypoxia on lung ODC activity. Studies of neonatal hypoxia require the dams to be absent during the gassing period as they become extremely agitated under the low $\mathrm{O}_{2}$ conditions. Because even short-term interruption of mother-pup interactions are known to decrease ODC levels in most tissues (31), we also measured enzyme activity in rat pups that were left with their dams for the duration of the experiment. As shown in Table 1, exposure to $7 \% \mathrm{O}_{2}$ for 1,2 , or $4 \mathrm{~h}$ markedly increased lung ODC activity, whether compared with that of separated animals gassed with room air or that of control rats (left with their mothers).

Metenkephalin has also been shown to cause respiratory depression $(41,42)$. Therefore, to further investigate the potential role of hypoxia on the ODC effect of BE, we measured lung ODC activity in rats given metenkephalin i.c. Administration of doses of metenkephalin as high as $1.65 \mu \mathrm{g} / \mathrm{g}$ brain wt (10 times the highest dose of $\mathrm{BE}$ used in our studies, on a molecular weight 
basis) had no overall significant effect on enzyme activity (data not shown).

The possibility that the decreases in ODC activity reflect nonspecific toxic responses to BE was investigated through measurements of protein synthesis, as assessed by $\left[{ }^{3} \mathrm{H}\right]$ leucine incorporation into trichloroacetic-precipitable material. Rats were injected i.c. with $\mathrm{BE}$ followed $1 \mathrm{~h}$ later by a s.c. injection of $\left[{ }^{3} \mathrm{H}\right]$ leucine $(0.5 \mu \mathrm{Ci} / \mathrm{g}$ body wt), and protein synthesis was determined 20, 40, and $80 \mathrm{~min}$ after the second injection. BE treatment did not alter the percentage of $\left[{ }^{3} \mathrm{H}\right]$ leucine incorporation into proteins as analyzed by two-way analysis of variance (control groups $=27.7 \pm 0.6,34.4 \pm 1.3$, and $39.5 \pm 0.5 ; \mathrm{BE}$ groups $=$ $24.9 \pm 1.1,33.0 \pm 1.7$, and $45.3 \pm 1.3$ at 20,40 , and $80 \mathrm{~min}$, respectively; data represent the means \pm SEM of values from nine to 19 animals/group/time point).

Effect of $B E$ on lung ODC activity in rats of different ages. In agreement with previous reports, control animals showed a peak in basal lung ODC activity at $6 \mathrm{~d}$ of age followed by a decrease to very low values at postnatal d 14 and a substantial late rise in enzyme activity from postnatal d 18-30 (26, 29) (Fig. 5). BE administration inhibited tissue ODC activity during the first 2 wk of age, but had no effect on 18- or 30-d-old animals.

\section{DISCUSSION}

The results from these studies demonstrate that ODC activity in the neonatal rat lung is highly sensitive to changes in CNS BE levels. We found that i.c. doses of BE as low as $0.5 \mu \mathrm{g} / \mathrm{g}$ brain wt significantly decreased ODC activity. Subcutaneous administration of even 10 times the highest amount of $\mathrm{BE}$ given i.c. did not alter lung ODC activity, indicating that the effect results indirectly from CNS actions of BE. Centrally mediated effects of CNS BE on other peripheral tissues have been recently reported by our laboratory $(14,43,44)$.

Coadministration of naloxone with $\mathrm{BE}$ i.c. prevented the decreases in lung ODC activity evoked by BE alone, indicating an opioid-receptor-mediated phenomenon. This finding contrasts with our previous observations showing that the same dose of naloxone i.c. did not block the inhibitory effect of BE on liver ODC activity (14). Concurrent determinations of ODC activity in the lung and liver confirmed these tissue differences.

The postnatal rat lung progresses through three distinct developmental stages: saccular (up to d 4), proliferative (postnatal d

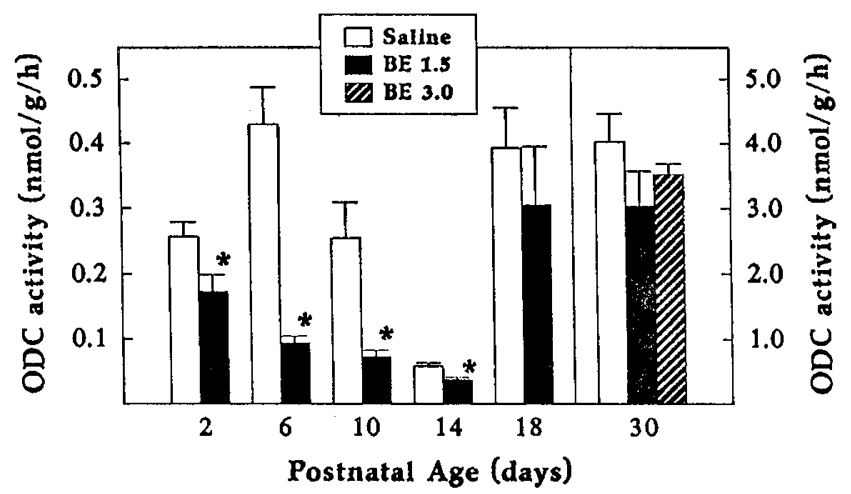

Fig. 5. Effect of central administration of BE on lung ODC activity in rats of different ages. At the ages indicated above, animals were injected i.c. with $1.5 \mu \mathrm{g}$ of $\mathrm{BE} / \mathrm{g}$ brain wt or saline, and ODC activity was measured $4 \mathrm{~h}$ later. Data represent the means \pm SEM of values from 7-17 animals/group at each age. Because of heterogeneity of variance, values were log-transformed before statistical evaluation. This manipulation gives equal weight to equivalent proportional changes, which is appropriate where data span a large range. Two-way log analysis of variance indicates significant effects of $\mathrm{BE}\left(F_{1}=47.9 ; p<0.01\right)$ and age $\left(F_{5}=115.2 ; p<0.01\right)$, as well as an interaction of $\mathrm{BE}$ and age $\left(F_{5}=\right.$ $3.40 ; p<0.01)$. Asterisks denote significant differences of individual BE groups $v s$ saline as evaluated by $t$ test $(p<0.05$ or less).
4-13), and terminal differentiation (postnatal d 14-21) (15). The opioid effect was clearly seen on postnatal d 2-14 but was no longer apparent by postnatal d 18 . The insensitivity to BE during the terminal differentiation period could not be explained by its typically low basal ODC levels inasmuch as 30-d-old pups (whose basal lung ODC activity is very high) also did not respond to $\mathrm{BE}$, even when twice the dose of $\mathrm{BE}$ administered to younger pups was used.

Enzyme kinetic studies eliminated the possible participation of a posttranslational inhibitor, inasmuch as no significant changes in $\mathrm{Km}$ were obtained. This would be expected if changes in enzyme affinity for ornithine had occurred $(35,45)$. In contrast, ODC $V_{\max }$ in BE-treated rats was approximately $70 \%$ lower than control values, a decrease similar to that of ODC activity. It is then clear that $\mathrm{BE}$ reduces lung ODC activity by inhibiting its de novo synthesis rather than by a posttranslational mechanism.

$\mathrm{BE}$ has been reported to cause respiratory depression in dogs (39), suggesting that the decreases in lung ODC activity we have observed in BE-treated rat pups may result from actions of this neuropeptide on ventilation. The following observations, however, make this possibility unlikely. 1) We found that 6-d-old rats exposed to hypoxia $\left(7 \% \mathrm{O}_{2}\right.$ for 1 to $\left.4 \mathrm{~h}\right)$ actually showed profound increases in lung ODC activity. 2) Metenkephalin, which has also been shown to cause respiratory depression (41, 42 ), did not alter lung ODC activity even when five times the highest dose of BE used in these studies was administered. 3) The respiratory actions of $\mathrm{BE}$ were naloxone reversible (39). Accordingly, this opioid antagonist should also block the ODC effect in all tissues if both phenomena are causally related. Although naloxone reversed BE's action on lung ODC (in this study), it did not prevent the effect on liver ODC (14). 4) Furthermore, rat pups given $0.15 \mu \mathrm{g} \mathrm{BE} / \mathrm{g}$ brain wt, a dose that did not significantly alter rectal temperature (an index of metabolic activity), showed significant decreases in brain and liver DNA synthesis (44). 5) Finally, the ODC effect could not be attributed to a generalized toxic response as protein synthesis was not altered.

At first, BE's inhibition of ODC activity appears to contradict the postulated acceleration of lung maturation by endogenous opioids, but this might not be the case. Although pulmonary function in premature offspring born to opiate-addicted mothers is similar to that found in full-term offspring born to normal mothers (4-7), body weights are markedly subnormal (1). Glucocorticoids are also known to evoke dichotomous developmental effects. For example, dexamethasone accelerates the development of lung function by enhancing surfactant synthesis (19), but simultaneously slows down proliferation of lung cells as indicated by reduced ODC activity and DNA/lung ratios (26, 46). In fact, because we found increased plasma corticosterone concentrations after $\mathrm{BE}$ administration, it is possible that CNS $\mathrm{BE}$ may influence lung maturation through an indirect action on glucocorticoids/stress mechanisms.

Because changes in ODC levels during early postnatal life are indicative of perturbations in cell development, the results from these studies suggest that activation of endogenous CNS BE systems may have a significant impact on lung maturation. Indeed, results from recent studies conducted in our laboratory show that i.c. administration of doses of BE that significantly reduce ODC activity also profoundly decrease lung DNA synthesis (unpublished experiments). Because changes in DNA biosynthetic rates reflect alterations in cell replication, increases in CNS BE levels during early postnatal life could retard lung growth. It can be speculated that, in a manner similar to that of glucocorticoids, the natural release of $\mathrm{BE}$ at birth $(9,10,12)$ may favor critical events necessary for early adaptation to extrauterine life (such as surfactant production) by restricting the amount of cellular energy directed toward growth-related processes, including ODC activity and DNA synthesis. 


\section{REFERENCES}

1. Zelson C, Rubio E, Wasserman E 1971 Neonatal narcotic addiction: 10-year observation. Pediatrics 48:178-189

2. Zelson C, Lee SJ, Casalino M 1973 Neonatal narcotic addiction: comparative effects of maternal intake of heroin and methadone. N Engl J Med 23:12161220

3. Ramer CM, Lodge A 1975 Neonatal addiction: a two-year study. Part I: clinical and developmental characteristics of infants of mothers on methadone maintenance. Addict Dis 2:227-234

4. Gluck L, Kulovich MV 1973 Lecithin/sphingomyelin ratios in amniotic fluid in normal and abnormal pregnancy. Am J Obstet Gynecol 115:539-546

5. Glass L, Rajegowda BK, Evans HE 1971 Absence of respiratory distress syndrome in premature infants of heroin-addicted mothers. Lancet 2:685686

6. Taeusch HW, Carson SH, Wang NS, Avery ME 1973 Heroin induction of lung maturation and growth retardation in fetal rabbits. J Pediatr 82:869875

7. Comer CR, Grunstein JS, Mason RJ, Hohnston SC, Grunstein MM 1987 Endogenous opioids modulate fetal rabbit lung maturation. J Appl Physiol 62:2141-2146

8. Bianchi M, Marini A, Sacerdote P, Cocco E, Brini A, Panerai AE 1988 Effect of chronic morphine on plasma and brain beta-endorphin and methionine enkephalin in pregnant rats and in their fetuses or newborn. Neuroendocrinology 47:89-94

9. Panerai AE, Martini A, Di Giulio AM, Fraioli F, Vegni C, Pardi G, Marini A, Mantegazza P 1983 Plasma beta-endorphin, beta-lipotropin, and met-enkephalin concentrations during pregnancy in normal and drug-addicted women and their newborn. J Clin Endocrinol Metab 57:537-543

10. Moss IR, Conner H, Yee WFH, Iorio P, Scarpelli EM 1982 Human betaendorphin-like immunoreactivity in the perinatal/neonatal period. J Pediatr 101:443-446

11. Marzullo G, Friedhoff AJ 1980 Opiate binding and cerebroside sulfates in brain and lung of developing chick. In: Way EL (ed) Endogenous and Exogenous Opiate Agonists and Antagonists. Pergamon Press, New York, pp 47-50

12. Iny LJ, Gianoulakis C, Palmour RM, Meaney MJ 1987 The beta-endorphin response to stress during postnatal development in the rat. Dev Brain Res $31: 177-181$

13. Zagon IS, McLaughlin PJ 1985 Opioid antagonist-induced regulation of organ development. Physiol Behav 34:507-511

14. Bartolome JV, Bartolome MB, Daltner LA, Evans CJ, Barchas JD, Kuhn CM Schanberg SM 1986 Effects of beta-endorphin on ornithine decarboxylase in tissues of developing rats: a potential role for this endogenous neuropeptide in the modulation of tissue growth. Life Sci 38:2355-2362

15. Burri PH, Dbaly J, Weibel ER 1974 The postnatal growth of the rat lung. I. Morphometry. Anat Rec 178:711-730

16. Kauffman SL, Burri PH, Weibel ER 1974 The postnatal growth of the rat lung. II. Autoradiography. Anat Rec 180:63-76

17. Burri PH 1974 The postnatal growth of the rat lung. III. Morphology. Anat $\operatorname{Rec} 180: 77-98$

18. Burri PH 1987 Postnatal lung development and modulation of lung growth In: Walters DV (ed) Physiology of the Fetal and Neonatal Lung. Proceedings of the International Symposium on Physiology and Pathophysiology of the Fetal and Neonatal Lung. MTP Press, Lancaster, England, pp 39-55

19. Morishige WK, Joun NS 1982 Influence of glucocorticoids on postnatal lung development in the rat: possible modulation by thyroid hormone. Endocrinology 111:1587-1594

20. Morishige WK, Joun NS, Guernsey DL 1982 Thyroidal influence on postnatal lung development in the rat. Endocrinology 110:444-451

21. Kodama M, Inoue F, Nakayama T 1987 Induction of ornithine decarboxylase activity in rat lung by neurotransmitters and peptide hormones. Anticancer Res 7:1287-1292

22. Slotkin TA, Bartolome J 1983 Ornithine decarboxylase: marker of neuroendocrine and neurotransmitter actions. Methods Enzymol 103:590-603
23. Pegg AE, McCann PP 1982 Polyamine metabolism and function. Am J Physiol 243.C212-C221

24. Heby O 1981 Role of polyamines in the control of cell proliferation and differentiation. Differentiation 19:1-20

25. Butler SR, Schanberg SM 1975 Effect of maternal morphine administration on neonatal rat brain ornithine decarboxylase (ODC). Biochem Pharmacol 24:1915-1918

26. Navarro HA, Lachowicz J, Bartolome J, Whitmore WL, Slotkin TA 1988 Effects of prenatal dexamethasone on development of ornithine decarboxylase activity in brain and peripheral tissues of rats. Pediatr Res 24:465-469

27. Anderson TR, Schanberg SM 1975 Effect of thyroxine and cortisol on brain ornithine decarboxylase activity and swimming behavior in developing rat. Biochem Pharmacol 24:495-501

28. Slotkin TA, Seidler FJ, Whitmore WL 1980 Effects of maternal methadone administration on ornithine decarboxylase in brain and heart of the offspring: relationships of enzyme activity to dose and to growth impairment in the rat. Life Sci 26:861-867

29. Thet LA, Parra SC 1986 Role of ornithine decarboxylase and polyamines in early postnatal lung development. J Appl Physiol 61:1661-1666

30. Slotkin TA, Cowdery TS, Orband L, Pachman S, Whitmore WL 1986 Effects of neonatal hypoxia on brain development in the rat: immediate and longterm biochemical alterations in discrete regions. Brain Res 374:63-74

31. Schanberg SM, Evoniuk G, Kuhn CM 1984 Tactile and nutritional aspects of maternal care: specific regulators of neuroendocrine function and cellular development. Proc Soc Exp Biol Med 175:135-146

32. Slotkin TA, Persons D, Slepetis RJ, Taylor D, Bartolome J 1984 Control of nucleic acid and protein synthesis in developing brain, kidney and heart of the neonatal rat: effects of alpha-difluoromethylornithine, a specific, irreversible inhibitor of ornithine decarboxylase. Teratology 30:211-224

33. Russell DH, Snyder SH 1968 Amine synthesis in rapidly growing tissues Ornithine decarboxylase activity in regenerating rat liver, chick embryo, and various tumors. Proc Natl Acad Sci USA 60:1420-1427

34. Butler SR, Schanberg SM 1976 Apparent kinetic differences between brain and liver ornithine decarboxylase. Life Sci 18:759-762

35. Lau C, Slotkin TA 1979 Regulation of rat heart ornithine decarboxylase: change in affinity for ornithine evoked by neuronal, hormonal, and ontogenetic stimuli. Mol Pharmacol 16:504-512

36. Morris G, Lau C, Slotkin TA 1983 Regulation of brain ornithine decarboxylase activity in the neonatal rat. Eur J Pharmacol 88:177-184

37. Metcalf BW, Bey P, Danzin C, Jung MJ, Casara P, Vevert JP 1978 Catalytic irreversible inhibition of mammalian ornithine decarboxylase (E.C.4.1.1.17) by substrate and product analogues. J Am Chem Soc 100:2551-2553

38. Bartolome JV, Bartolome MB, Harris EB, Schanberg SM 1987 N-alpha-acetylbeta-endorphin stimulates ornithine decarboxylase activity in preweanling rat pups: opioid- and non-opioid-mediated mechanisms. J Pharmacol Exp Ther 240:895-899

39. Moss IR, Friedman E 1978 Beta-endorphin: effects on respiratory regulation. Life Sci 23:1271-1276

40. Weil JV, McCullough RE, Kline JS, Sodal IE 1975 Diminished ventilatory response to hypoxia and hypercapnia after morphine in normal man. $\mathrm{N}$ Eng J Med 292:1 103-1106

41. Florez J, Mediavilla A 1977 Respiratory and cardiovascular effects of metenkephalin applied to the ventral surface of the brain stem. Brain Res 138:585-590

42. Denavit-Saubie M, Campagnat J, Zieglgansberger W 1978 Effects of opiates and methionine-enkephalin on pontine and bulbar respiratory neurons of the cat. Brain Res 155:55-67

43. Bartolome JV Bartolome MB, Harris EB, Pauk JS, Schanberg SM 1989 Regulation of insulin and glucose plasma levels by central nervous system beta-endorphin in preweanling rats. Endocrinology 124:2153-2158

44. Bartolome JV, Bartolome MB, Lorber BA, Dileo SJ, Schanberg SM 1990 Effects of central administration of beta-endorphin on brain and liver DNA synthesis in preweanling rats. Neuroscience (in press)

45. Lau C, Slotkin TA 1982 Stimulation of rat heart ornithine decarboxylase by isoproterenol: evidence for post-translational control of enzyme activity? Eur J Pharmacol 78:99-105

46. Carson SH, Taeusch Jr HW, Avery ME 1973 Inhibition of lung cell division after hydrocortisone injection into fetal rabbits. J Appl Physiol 34:660-663 